Viewpoints and Letters to the Editor are published in Hort- comments on matters of concern to horticulturists. These are Science to provide members of the American Society for Hor- not statements of official Society policy nor do they necessarticultural Science an opportunity to share their experiences and ily reflect the views of a majority of the Society's members.

\title{
Few Cytoplasm Contribute to North American Strawberry Cultivars
}

\author{
Adam Dale \\ Horticultural Research Institute of Ontario, Box 587, Simcoe, ON, N3Y 4N5 Canada \\ Thomas M. Sjulin \\ Driscoll Strawberry Associates, 404 San Juan Road, Watsonville, CA 95076
}

\begin{abstract}
The cytoplasm of plants contains genetic information that is transmitted maternally. All progeny from a single female plant will share the same extra-chromosomal genes unless a mutation occurs. To date, the strawberry (Fragaria $\times$ ananassa Duch.) has not been analyzed to show the cytoplasmic contribution of different maternal founding clones to the gene pool of North American cultivars. This report summarizes the contribution played by the maternal founding clones to the cytoplasm. of the present North American cultivars.
\end{abstract}

The 134 cultivars of known parentage released in North America between 1960 and 1987 were used as the database, and the pedigree tables assembled by Sjulin and Dale (1987) were used as the basis for this study. The cytoplasm of each cultivar was traced by following pedigrees back to the original maternal parent or the last clone of known parentage.

Only 17 cytoplasm were identified in the 134 cultivars of known parentage (Table 1), considerably fewer than the 53 founding clones identified by Sjulin and Dale (1987). Three of the cytoplasm were traced to their native founding clones, while the others were traced to old cultivars whose origins could not be determined due to incomplete records. Therefore, there are almost certainly even fewer cytoplasm involved than 17 . The exact number of founding cytoplasm could probably be inferred from assays of the mitochondrial and chloroplast DNA.

Cultivars with a single cytoplasm were sorted into 11 groups based on geographical origin (Sjulin and Dale, 1987) to see if the groups contained few or unique cytoplasm. The contribution of the cytoplasm varied among these groups. Those of 'Missionary' and 'Hudson Bay' are evenly distributed, each in six of the 11 groups, whereas the cytoplasm of 'Middlefield' (13/18 in California

Received for publication 16 Oct. 1989. We thank J.F. Hancock for his critical comments on the original manuscript. The cost of publishing this paper was defrayed in part by the payment of page charges. Under postal regulations, this paper therefore must be hereby marked advertisement solely to indicate this fact. group), 'Chesapeake' (11/13 in southeastern group), 'Aberdeen' (11/12 in northeastern group), and 'Marshall' (nine/nine in northern everbearing group), and $F$. virginiana 'The Native Iowa' (six/seven in southeastern group) are restricted mainly to one group.

The contribution of cytoplasmic genes to the improvement of the strawberry has not been investigated in detail. Only a few studies showing differences between reciprocal crosses have been described (Barritt et al., 1982; Sjulin et al., 1986). June yellows is thought to be transmitted by cytoplasmic genes (Scott and Lawrence, 1975), and susceptible cultivars have included those with cytoplasm from five founding clones.

Steps should be taken to introduce new cytoplasm to avoid the increased risk of del- eterious effects such as June yellows. With so few cytoplasm present, cultivars of widely differing germplasm may have identical cytoplasm. As the non-nuclear genes in the cytoplasm cannot be introduced by crossing, a program to extend the cytoplasm base of the crop should be considered.

Two strategies can and are being adopted by North American strawberry breeding programs to increase cytoplasmic diversity. These are to a) increase the number of cultivars with known different cytoplasm that are used as female parents, and b) introduce cytoplasm from wild Fragaria spp.

Probably the most promising of the two strategies is to introduce cytoplasm from wild Fragaria spp. Several collections of wild species recently have been announced, both

Table 1. All North American strawberry cultivars of known parentage released between 1960 and 1987, grouped according to their maternal founding clone.

\begin{tabular}{|c|c|}
\hline Maternal founding clone & Cultivars \\
\hline Missionary & $\begin{array}{l}\text { American Sweetheart, Annapolis, Blomidon, Cataldo, Dabreak, Fresno, } \\
\text { Glooscap, Mars, Micmac, Midway, Nisqually, Quinault, Rainier, } \\
\text { Scott, Shuksan, Stoplight, Suntise, Tangi, Tioga, Torrey, Vantage }\end{array}$ \\
\hline Hudson Bay & $\begin{array}{l}\text { Aliso, Aptos, Badgerbelle, Deep Red, Dover, Florida Belle, Gala, } \\
\text { Garnet, Honeylump, Northland, Red Titan, Santana, Sequoia, } \\
\text { Trumpeter, Ulrich, Veegem, Veestar, Wiltguard }\end{array}$ \\
\hline Middlefield & $\begin{array}{l}\text { Aiko, Bounty, Brighton, Cascade, Chandler, Cruz, Douglas, Fern, } \\
\text { Hecker, Marlate, Parker, Salinas, Selva, Soquel, Toro, Tufts, Tus- } \\
\text { tin, Vista }\end{array}$ \\
\hline Chesapeake & $\begin{array}{l}\text { Allstar, Apollo, Atlas, Guardian, Linn, Prelude, Redchief, Secord, } \\
\text { Sentinel, Sumner, Titan, Tribute, Tristar }\end{array}$ \\
\hline Aberdeen & $\begin{array}{l}\text { Acadia, Citation, Cornwallis, Darrow, Earliglow, Governor Simcoe, } \\
\text { Holiday, Jewel, Kent, Lester, Raritan, Veeglow }\end{array}$ \\
\hline Marshall & $\begin{array}{l}\text { Amazing, Autumn Surprise, Fantasy, Shortcake, Spring Beauty, Spring } \\
\text { Giant, Sunburst, Temptation, Universal Red }\end{array}$ \\
\hline Neunan & $\begin{array}{l}\text { Benton, Fortune, Molalla, Nedspride, Olympus, Pajaro, Tillicum, To- } \\
\text { tem, Tyee }\end{array}$ \\
\hline Early Jersey Giant & $\begin{array}{l}\text { Candy Red, Gilbert, Locke Lake Ruby, Millay Everbearer, Red Giant, } \\
\text { Royalty, Sweet Abundance, Sweet Surprise }\end{array}$ \\
\hline \multicolumn{2}{|r|}{ 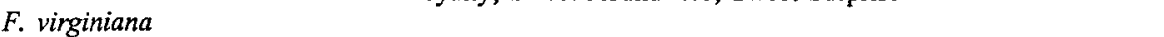 } \\
\hline 'The Native Iowa' & Arking, Cardinal, Comet, Delite, Earlibelle, Earlimiss, Rosanne \\
\hline Ettersburg 450 & Badgerglo, Honeoye, Vesper, Vibrant \\
\hline $\begin{array}{l}\text { Champion } \\
F \text { chiloensi }\end{array}$ & Ourown, Porter's Pride, Protem, Tendersweet \\
\hline 'Cape Mendocino' & Cheam, Hood, Vale \\
\hline Bubach & Centennial, Chief Bemidji \\
\hline Markee & Alaska Pioneer, Canoga \\
\hline $\begin{array}{l}\text { Streamliner } \\
\text { F. chiloensis }\end{array}$ & Fort Laramie, Geneva \\
\hline 'Reedsport' & Columbia \\
\hline Driscoll E 101:10 & Heidi \\
\hline
\end{tabular}


of $F$. chiloensis from California (Hancock and Bringhurst, 1979), Washington and Oregon (Crock et al., 1982), and British Columbia (Daubeny and Frazer, 1987), and $F$. virginiana from Minnesota (Stabler et al., 1987) and Ontario (Dale, 1988). However, about half the clones selected from these programs will be unavailable as female parents because they are pollen parents only.

The two strategies mentioned should be used to increase the cytoplasmic variation in North American strawberries. This can be achieved without diverting resources from efforts to increase nuclear genetic diversity by careful selection of female parents within existing breeding programs. However, more information is needed to determine the role played by cytoplasmic variation in the development of new strawberry cultivars.

\section{Literature Cited}

Barritt, B.H., R.S. Bringhurst, and V. Voth. 1982. Inheritance of early flowering in relation to breeding day-neutral strawberries. J. Amer. Soc. Hort. Sci. 107:733-736.

Crock, J.E., C.H. Shanks, Jr., and B.H. Barritt. 1982. Resistance in Fragaria chiloensis and $F$. $x$ ananassa to the aphids Chaetosiphon fragaefolii and C. thomasi. HortScience 17:959-960.

Dale, A. 1988. Variation in wild strawberry in Ontario. Rpt. Commun. Hort. Res. for 1987. Canadian Hort. Council, Ottawa. p. 17.

Daubeny, H. and B.D. Frazer. 1987. The British Columbia Fragaria chiloensis collection. Rept. Commun. Hort. Res. for 1986. Canadian Hort. Council, Ottawa. p. 80.

Hancock, J.F., Jr., and R.S. Bringhurst. 1979. Ecological differentiation in perennial, octoploid species of Fragaria. Amer. J. Bot. 66:367375.

Scott, D.H. and F.J. Lawrence. 1975. Strawberries, p. 71-97. In: J. Janick and J.N. Moore (eds.). Advances in fruit breeding. Purdue Univ. Press, West Lafayette, Ind.

Sjulin, T.M. and A. Dale. 1987. Genetic diversity of North American strawberry cultivars. J. Amer. Soc. Hort. Sci. 112:375-385.

Sjulin, T.M., J. Robbins, and B.H. Barritt. 1986. Selection for virus tolerance in strawberry. J. Amer. Soc. Hort. Sci. 11:458-464.

Stabler, M.M., J.J. Luby, and P.D. Ascher. 1987. Evaluation of repeat-flowering and sex expression in wild populations of Fragaria virginiana. HortScience 22:1076. (Abstr.)

\section{Corrigendum}

- In the article "Influence of Endocarp Thickness on Rose Achene Germination: Genetic and Environmental Factors", by Serge Gudin, Laurence Arene, André Chav-

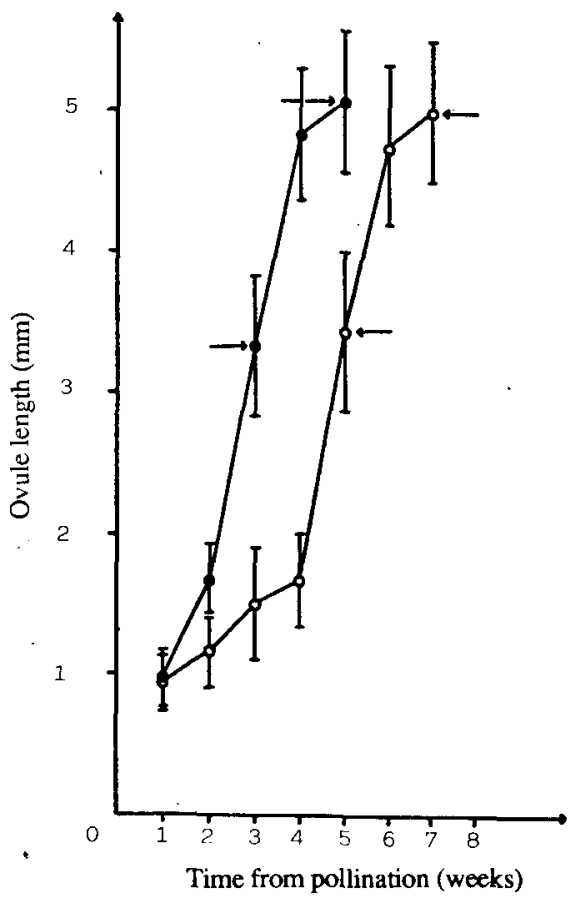

Fig. 1. Ovule length of 'Meiringa' $x$ 'Meitulandi' $(0)$ or $x$ 'Pink Puff' $(\bullet)$ roses until embryos are "visible". For both curves, the first arrow signals the time when the difference between fecund and nonfecund ovules becomes noticeable; the second signals the time when embryos are visible. agnat, and Camille Bulard [HortScience 25(7):786-788, July 1990], the text and numbers were not included on the $\mathrm{x}$ and $\mathrm{y}$ axes of Figs. 1 and 2. The authors' revised figures are as follows:

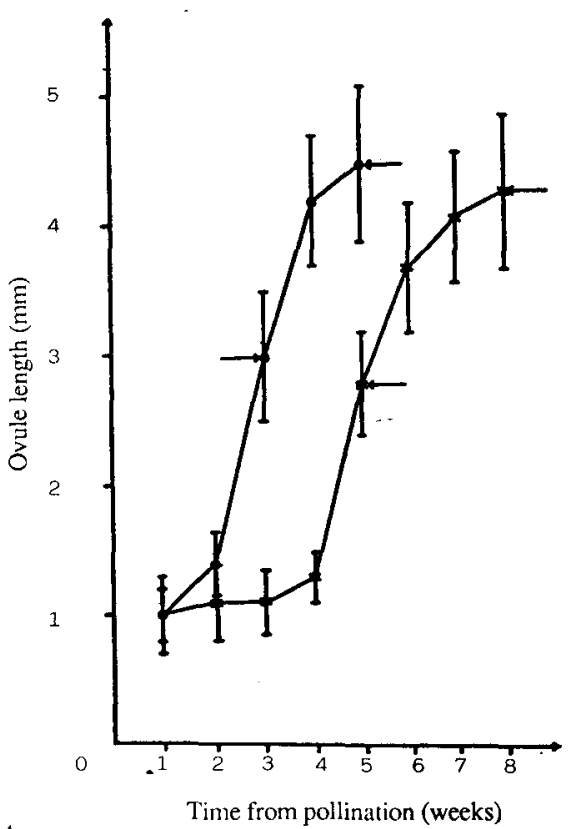

Fig. 2. Ovule length of no. 364-73. $D \times$ 'Jelrafloki' from May $(\bullet)$ or March $\left({ }^{*}\right)$ pollinations until embryos are "visible". For both curves, the first arrow signals the time when the difference between fecund and nonfecund ovules becomes noticeable; the second signals the time when embryos are visible. 